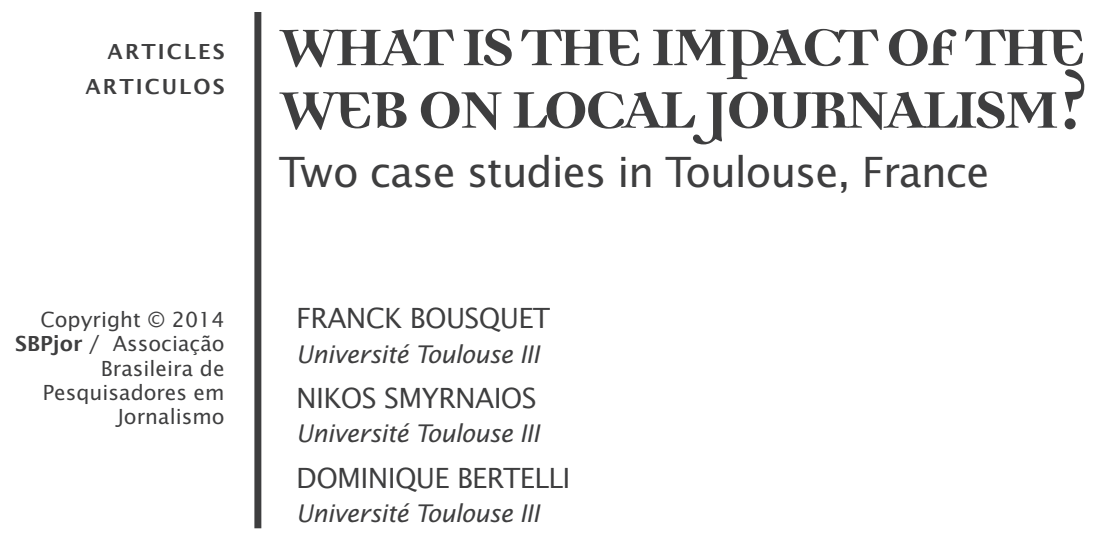

\begin{abstract}
Our article aims to explore how the emergence of independent journalism could reconfigure local news. Our field research, carried out from January to April 2013, focuses on two news-based websites in Toulouse: Carré d'infos and LibéToulouse. The results of our research show how newcomers to the world of independent journalism are struggling to maintain their business. A business which is even more precarious than that of their national counterparts, also highlighting the low number of readers and limited exposure they get within the local public space. However, our study has shown that these new players concentrate on field reporting, covering issues that mainstream media often does not and, in particular, cherishing their independence from local politics and economics.
\end{abstract}

Keywords: Pure players. France. Toulouse. Journalism. Local news

\title{
O IMPACTO DA WEB NO JORNALISMO LOCAL: dois estudos de caso na cidade de Toulouse
}

RESUMO - Nosso artigo pretende explorar a forma pela qual a emergência de start-ups jornalísticas não relacionadas com a mídia tradicional poderia reconfigurar o noticiário local. Nossa pesquisa de campo, realizada entre janeiro e abril de 2013, focalizou dois websites que cobrem notícias em Toulouse: Carré d'infos e LibéToulouse. Os resultados mostraram como os recém-chegados lutam para manter um modelo de negócio, que é até mais precário do que o de seus similares de âmbito nacional, e apontou a baixa audiência e a visibilidade limitada que obtêm no espaço público local. Nosso estudo mostrou ainda que esses novos agentes concentram-se em reportagem de campo, cobrindo pautas geralmente fora da agenda principal e valorizam particularmente sua independência da política local e do poder econômico.

Palavras-chave: Pure players. França. Toulouse. Jornalismo. Noticiário local. 


\section{EL IMPACTO DE LA RED EN EL PERIODISMO LOCAL: dos estudios de caso en la ciudad de Toulouse}

RESUMEN - Este artículo pretende explorar la forma en que el surgimiento de nuevas empresas periodísticas no relacionadas con los medios de comunicación tradicionales podría reconfigurar los noticiarios locales. La investigación de campo, llevado a cabo entre enero y abril de 2013, se centra en dossitios electrónicos que cubren noticias en Toulouse: Carré d'infos y LibéToulouse. Los resultados muestran cómo los recién llegados luchan por mantener un modelo de negocio que es incluso más precario que el de sus homólogos a nivel nacional, y señalan la baja audiencia y la visibilidad limitada que consiguen en del espacio público local. Asimismo, el estudio pone de manifiesto que estos nuevos agentes se concentran en el reportaje sobre el terreno, cubriendo temas a menudo fuera de la agenda principal, y valoran fundamentalmente su independencia del poder político y económico local.

Palabras clave: Emprendimientos solo en línea (pure players). Francia. Toulouse. Periodismo. Noticiario local.

The increasing prerogatives and means of local political power over the last few decades in France have brought forth questions regarding the networks of information available for people to form their opinions on local issues and electoral choices. Even though new political forms of mediation in local and regional public spaces have emerged since the decentralisation laws of 1983 (PAILLART, 1993; CARDY, 1997), local news has mostly been based on the models of the Regional Daily Press (RDP) and the Local Weekly Press (LWP). These models revolve around three main axes: practical information (FEYEL, 1999), support for local politicians (MARTIN, 2002), and articulation with national public space (DE LA HAYE, 1984).

From the outside, the infra-national media landscape (hyperlocal, local, and regional news) in France is quite diverse: daily and weekly newspapers, local and regional radio broadcasts, city and nation-wide television networks, local and regional state-owned television stations, as well as all the communication tools adopted by different local actors.

However, decentralisation has reinforced the RDP's monopolistic hold on media, effectively reducing the number of other press groups while at the same time increasing its coverage 
areas (LE FLOCH, 1997). Moreover, regional newspapers depend on government authorities and community integration both economically and organizationally (GIMBERT, 2012; FRISQUE, 2010).

Like their national and international counterparts, local media has also been going through important changes brought on by the Internet over the last few years. The emergence of local and regional digital actors seems to indicate a diversification of the concept of news and a refreshing approach to local political issues. Furthermore, pure players (news websites originating online) are the only actors providing a wider range of content on the national scene by offering an original insight into issues not covered by mainstream media (MARTY et al., 2012).

However, since the foundation of Libération in 1973, no daily newspaper in France has been able to establish itself as a news frontrunner. Therefore, the emergence of pure players in Paris, 2007, and the new forms of online journalism they represented was significant. For instance, Mediapart and Rue 89 represent new editorial and business models. Mediapart was launched in 2008 by former Le Monde editor, Edwy Plenel, mostly known for his commitment to controversial journalism and as being a kind of political and economic watchdog. Therefore, investigative journalism has become Mediapart's focus. Mediapart is one of the few pure players which has achieved economic stability thanks to its 70,000 subscribers paying 9 euros a month. Rue 89 is the work of former Libération journalists Pierre Haski, Laurent Mauriac and Pascal Riché. They launched the site in the spring of 2007, the same year Nicolas Sakorzy won the presidential election. Rue 89 highlights social issues as well as day-to-day life and entertainment. It also puts an emphasis on user-participation in news production. Due to the fact it was a free newspaper, Rue 89 counted on revenue from advertising and other services (training, by-product sales, etc.), but these were not sufficient enough for the site to break even. In an attempt to increase its online audience, the Le Nouvel Observateur group purchased Rue 89 in 2013, even though it ran the subsequent risk of compromising its original editorial project (SMYRNAIOS, 2014). Both titles and many other Parisbased pure players such as Atlantico.fr, Slate.fr, and Arrêt sur images are important because they provided editorial and business reference models for many developing independent news websites at a local level.

Results from a previous study comparing a dominant regional online newspaper (La Dépêche du Midi) to a local pure player (Ariège news) confirmed that online news producers have a tendency to redefine the local news sector (BOUSQUET; SMYRNAIOS, 2013). Even though 
the online and printed editions of La Dépêche du Midi are dominant publications, the newspaper finds itself in somewhat of a paradox. While its online strategy is to focus on a broader audience and search engine result positions, the printed edition sticks to the model of accepted news media and fosters institutional communication. What ensues is a much different approach to news than what investigative journalism uses, highlighted by a willingness to enhance the government's actions. La Dépêche's position therefore allows for local independent online news sites to develop within the same circulation area.

Our field research enabled us to identify newcomers on the local media scene:

- The national media, with regional press offices set up in large cities and operating under the same model as national offices. Libération pioneered this movement by having launched eight local online editions since 2007;

- The local independent pure players attempt to find new ways of building and producing regional news, and work under the same model as their national counterparts, sometimes in collaboration with them. Dijonscope in Dijon, Aqui.fr in Bordeaux, Grand Rouen in Rouen, Carré d'info in Toulouse or Marsactu in Marseille are all among these newcomers.

- The local or national internet companies looking to increase the value of their businesses by partnering with big telecom corporations (like Orange, which bought Cityvox cityguide), or regional communication and advertising agencies which publish online directories or city guides providing information on leisure activities.

We therefore proposed the following questions about journalistic practices as well as the apparent diverse editorial and economic models of these media: Do these new actors reproduce the canonical form of local news (information services, subordination to local authorities, connections to politicians) or do they signal a reworking of editorial choices and local news production? Are they economically viable? If so, what are their respective strategies?

In order to answer these questions, we have conducted research in two areas: firstly, we questioned the business models developed by online media actors in order to better understand their links to local institutions; secondly, we questioned these same media actors' journalistic models by studying the production process of local news and the journalistic practices of those who run it. This two-fold approach allows us to address the political dimension of our topic. Firstly, by examining 
the sustainability of a diverse and independent news supply, and then by considering the interactions and balance of power which exist between the journalists and the differing social communities they report on.

Toulouse was selected as a case study in order to address the workings and evolution of these two levels. Of course, the three different actors we identified as newcomers on the local media scene are present in the Midi-Pyrénées capital. Nevertheless, since our research topic deals with the redefining of local news media (or the rethinking of public space at a local level) we focused on the national media's local ventures and the independent local pure players. A former study on public spaces in the Midi-Pyrénées region (BOUSQUET; SMYRNAIOS, 2010) showed that even though city guides are regarded as news, their participation in discussing local issues is marginal. Consequently, our sample for this article includes only two types of news websites: a blog run by the local correspondent of a national newspaper and an independent urban news website. Both disappeared in 2013 due to financial difficulties. Despite their economic failure, it is essential to consider these journalistic experiments when comparing them to established media journalists.

We apply a qualitative approach to our research method and to the semi-structured interviews of journalists working for the aforementioned media'. Additionally, we monitored the media every day over a period of several months and collected and analysed a body of various documents over this period: internal, financial and strategic documents, accounting data, institutional reports, and market and leadership research. After presenting the two websites, we will move on to study their respective journalistic practices and examine how they work with their sources. We will then see that while their form of local journalism differs from that of the big regional newspapers, they nevertheless work under the model of traditional media and lack the necessary resources to sustain their activities.

\section{PRESENTATION OF THE RESEARCH FIELD}

Founded in 1973 by intellectuals and young extreme leftwing journalists eager to provide free news, Libération became one of the main French daily newspapers in the 1980s. As the newspaper began expanding, Libération's board of directors launched two local versions in Toulouse and Lyon (RAMPON, 1999 ; GUISNEL, 2003). From 1986 to 1992, only Lyon Libération attempted to develop a new type of local news. Even though Gilbert Laval ${ }^{2}$ was brought on to 
keep Toulouse running, the project did not succeed.

Therefore, in 2007 Libération started launching online news sites in cities where its journalists or correspondents were already working. Envisioned as a local version of Libération, LibéToulouse. fr was a blog created at the end of the same year (yet this version never had any legal status). LibéToulouse was powered by several contributors: Gilbert Laval (website director and Toulouse-based journalist, who did not receive any additional compensation other than his salary as a correspondent), Jean-Manuel Escarnot (contracted stringer) and several volunteer stringers. The site was up and running by 2010 , registering between 300,000 and 400,000 visits per month. It had become an important actor in the Toulouse internet landscape at that time, even though it did not compare to Ladépêche.fr which registered more than 10 million visits a month. Up until 2011, a dozen correspondents were working for Libération's eight local websites: Bordeaux, Lille, Lyon, Marseille, Orléans, Rennes, Strasbourg and Toulouse. Since then, the newspaper has closed five of its sites run by stringers. At the turn of 2013, only the Toulouse, Marseille and Lyon websites were still active; cities where the newspaper's permanent journalists were working. They were definitively closed in April 2013.

Carré d'info was published by "B2X éditions" and created in 2011 by three young graduates. Xavier Lalu (28) and Bertrand Enjalabal (29), both holding a Master's degree in journalism from Toulouse's Institut d'Études Politiques, were the journalists and Xavier Druot (31) was in charge of business management and marketing. In 2012, Pauline Croquet (27), a Strasbourg School of Journalism graduate, joined the original trio. They were all partners and shareholders of Carré d'info, which received an average of 70,000 visitors per month in 2013 . They created the site after working several internships and temporary contracts. The initial investment of 48,000 euros came from their personal savings and a bank loan. Their business plan had them breaking even by mid-2014, but insufficient revenue forced the team to close the site down at the end of 2013.

Carré d'info's project was largely inspired on Rue 89. A publishing partnership was established between the two, the latter occasionally publishing articles written by the former. Carré d'info and its Paris model had the same goal: to give an original approach to news coverage in Toulouse by covering issues otherwise neglected by local media, adopting other points of view, and keeping well away from media and institutional agendas. Another of Carré d'info's 
missions was to encourage user participation in newsmaking while maintaining a high standard of journalism. The journalists refused to do sensationalist bits or sports reports primarily because they did not have the means to do so, but also because they wanted to differentiate themselves from their competitors.

\section{REFRESHED JOURNALISTIC PRACTICES}

The two sites referred to above developed refreshed journalism, different from that used in traditional local media. Before LibéToulouse was created, Gilbert Laval was a journalist working as a regional correspondent for a typical national newspaper. He was responsible for selecting regional news items of national or international interest and importance. On average he wrote one or two articles a week on current events. As a political columnist for Libération, he often travelled to Paris to work with the editorial staff and cover non-regional topics whenever necessary. However, the online version of Libération and the print media crisis changed everything.

As Gilbert Laval stated, he published two or three daily posts on LibéToulouse from 2007 to 2013 , reporting on national news with different objectives than those in his print articles. His first objective was immediacy: whereas a print journalist can afford to spend a few days thinking over a topic and gathering information, an online one can not. Their job is more immediate; they have less time for thinking on ideas and, consequently, less time for writing them. Gilbert Laval knew how online news worked and was well aware that regular news feeds and a continuous flow of information is needed in order to develop and maintain a website. He said this was the reason why he did not develop analytical approaches and contextualisation for LibéToulouse. His second objective was to encourage debates: the aim of the site was to use reader comments in order to facilitate discussion forums on the articles, which he himself moderated. LibéToulouse's editorial model is quite interesting because it combined methods of traditional journalism and blogging (immediacy and encouraging debates). Gilbert Laval doubled his working hours in order to keep his site constantly updated. He was always thinking of what his next post would be, which kept him constantly researching for news. He complied with the requirements of online writing while maintaining traditionalism in his journalism, concerning himself with maintaining 
the integrity of his employers. For instance, there were no links to external items in his articles. Therefore, LibéToulouse stood out among its peers, having only one link to the Libération website and another one leading to "Le Kiosque à musiques"; a page about various cultural sites in the Toulouse area. Unlike most bloggers in the public sphere, Gilbert Laval and his collaborators did not write editorials, never gave biased opinions, and followed the classic rules of writing taught in journalism schools.

LibéToulouse is a kind of hybrid object: on the one hand, it had the same constraints as traditional media introducing the online experience and ways of processing news inherited from the printed press, yet on the other hand, it fulfilled the prerequisites of expert Internet use and blogging rules. From an editorial point of view, this blog provided noteworthy news items and set up a chat room for its readers, all within a traditional journalistic framework adapted for the web.

As for Carré d'info, it published two feature articles and a few brief news items on a daily basis. The feature articles were based on field reports done on location, usually in the centre of Toulouse where the news bureau was located. All these articles used original photographs. Every week a different journalist was responsible for the news desk. This responsibility involved the following tasks, unrewarding in nature yet essential to the daily operations of the site: copydesk work (proofreading, correcting, headlining and publishing), administration of interactive features (updating Facebook and Twitter profiles, moderating and replying to comments) and brief news writings from a selection of carefully monitored links.

Each journalist had his or her favourite tool (also used for personal purposes) for monitoring Twitter. In addition to this, they would read the local press (La Dépêche du Midi, La Voix du Midi, Le Journal Toulousain, 20 minutes, etc.) and other local pure players on a daily basis to "check what they're doing". Reading RSS feeds was gradually replaced by using Twitter, which was more unpredictable but sometimes led to "lucky discoveries". Pauline Croquet always kept a "Toulouse" tab open on TweetDeck which helped her find newsworthy events. While specializing in local field reporting, Carré d'info's young editorial staff also used their online know-how for "virtual investigations". 


\section{A RELATION TO SOURCES DIFFERING FROM RDP JOURNALISTS}

LibéToulouse's news production was unique, for it combined instant publishing with the constant search for original news topics. Several other people (a contracted stringer, a volunteer specializing in rugby match reports, and a journalism student writing cultural reviews) also wrote content for the site under Gilbert Laval's supervision. As Laval pointed out and his website demonstrated, their job greatly differed from that of desk journalists in digital newsrooms (Estienne, 2007). He kept a constant eye on press agency dispatches, but his journalistic work consisted of personal investigations. As he put it, he did "his daily shopping" (pacing up and down, meeting representatives from institutions, economic and cultural actors...) and then decided what would "make the news". He did the same when he was a local correspondent for Libération, quite unlike newspaper journalists who wrote according to the institutions' agenda. Nevertheless, rhythm and goals changed through the creation of the Toulouse web site.

Rather than having a traditional journalist relationship with local institutional actors, he maintained an investigative one, considering and addressing officials as potential information sources. While it is true that local journalists frequently work with officials, they tend to circulate information rather than investigating or revealing it. LibéToulouse defined its own agenda within the regional public space and produced information outside the main agenda. It was the only exclusively online media site (along with several local or departmental ones) to produce general news in Midi-Pyrénées which did not just simply reproduce or re-write press releases. However, the publishing rate together with the urgency to post the latest news led to unedited and unprocessed news lacking contextualization ${ }^{3}$ and "points of view" as Gilbert Laval put it.

"We hate them and they give as good as they get". This is how Carré d'info journalists jokingly described their relationship with the institutions, one of the 'traditional' sources for local journalism. Due to a limited network of relations in Toulouse, the young journalists at Carré d'info did not have their own sources, nor did they have privileged access to official information. They were perceived as wrenches in the plans of the well-oiled Toulouse local news system which is based on close-knit relationships and collaborations between local government and journalists covering their activities (in particular La Dépêche du Midi).

For instance, the Mediathèque cultural centre wanted to hold debates in an attempt to expand its influence in Toulouse, yet they experienced some difficulties doing so. First, staff members 
at Médiathèque asked Carré d'info journalists to organize regular roundtables in order to liven up their "News section" (the newspapers and periodicals reading room). But, the city soon wanted to regain control of the debates due to their strong political themes. So, the Mediathèque's board of directors and the Mayor's office held a meeting where it was agreed that the topics and names of the participants were to be given in advance. In June 2013, as the city electoral campaign was about to begin, the Mayor also decided he wanted to take control of the issues and the participants, but the journalists refused.

Overall, the site's journalists get a mixed feedback from political representatives. The stakes are low when considering the site's small audience. Nevertheless, local councillors control what is written about them and do not hesitate to express their dissatisfaction if they feel they are getting unfavourable treatment from Carré d'info (something the Mayor himself did in the past).

The council communication services are also biased when it comes to the journalists (referring to them as "muck-rackers" and "pains in the neck"), unlike other media such as La Dépêche du Midi with whom they are accustomed to work. Furthermore, in some cases the journalists find it difficult to get interviews with key informants, in particular, with regional councillors. Proof of this is the anecdote relating to a debate on the TGV (high speed train) link between Toulouse and Bordeaux between the presidents of the Midi-Pyrénées and the Aquitaine regional councils. This debate was supposed to have been conducted by journalists from Carré d'info and the Bordeaux news site Aqui.fr' ${ }^{4}$. While the president of the Aquitaine region was willing to welcome Carré d'info journalists, the Midi-Pyrénées administration regional president, Martin Malvy, was not receptive to the idea and expressed his opinion by email only, which according to them, he had probably had an intern write for him.

In most cases, institutions treated the staff at Carré d'info like mere local bloggers, having no consideration or recognition for their journalistic work, even on a financial level: when they made a request to the regional council regarding an advertising contract for 2012, they were offered 50 euros...

\section{A NEW EMPHASIS ON THE READER}

LibéToulouse's manager placed great importance on the reader. Gilbert Laval acted first and foremost as a blogger, always attentive to the 
comments made about his articles, and even wrote back in order to fuel debates. Actually, a few dozen commentators quickly formed a small but generally well-informed community following the posts and discussing the political, economic and social issues in the Toulouse region. Some posts would rapidly attract several dozen comments depending on how they resonated with specific communities (for instance hunters, supporters of the Pyrénées wild bears, or the Occitan language). Gilbert Laval moderated the comments himself and often took part in the debates. He said this debating space was important to him because it allowed him to get in touch with a number of his readers on a daily basis. Such an attitude differs considerably from that of newspaper journalists at La Dépêche who are openly contemptuous of users posting comments in response to their articles (BOUSQUET; MARTY; SMYRNAIOS, 2013). However, the Internet restores the idea of dialogue and community, which is the very foundation of how journalists and correspondents integrate with local life (RINCOOT; ROCHARD, 2005). This small community quickly contributed to the development of the site, providing the reader with news on local life written by well-informed commentators.

Carré d'info had a different relationship with its readers. It received very few reader comments as it focused mainly on the social issues and magazine-style news of downtown Toulouse. However, the journalists, all young downtowners, were socially close to their public; they held meetings in public places or on online social networks.

As a matter of fact, Carré d'info organized public debates or film screenings and systematically took part in all sorts of organizations or university events. The screenings were organized in partnership with Rue 89, which paid for the copies of the films, whereas the debates were integrated into the editorial work. The journalists published an article presenting the elements of the debate and wrote a follow-up report. During our survey, two main debates took place: one on the creation of the TGV link between Toulouse and Bordeaux; and the other on problems relating to nightlife in the city centre. The debates proved fairly successful in terms of audience participation with over forty people in attendance. This type of event not only inspired new and original ideas for topics, but also helped to increase the site's popularity and profile in Toulouse.

Online social networks also provided a privileged means of communication with readers. Every article published online was systematically posted on the site's Facebook and Twitter accounts and added to the daily newsletter. The most relevant articles were also 
promoted on the journalists' own Facebook and Twitter accounts, or emailed directly to the contacts expressing an interest in them. Therefore, using Google Analytics to track traffic sources and content tools became essential for deciding which topic was worth publishing on social networks. Of course the editorial staff scrutinized how their articles were being shared on social networks, for they were a major target audience.

\section{THE NATIONAL FRAMING OF LOCAL NEWS}

We must consider another important point, namely the national reference as a constituent element of these two websites' identity. Indeed, the way both sites considered news was based on a model of public space related to national stakes and in accordance with the national debate organizational mode. LibéToulouse included this in the website's specifications and management, yet Carré d'info had more to do with the application of national standards of information and imitation of its Parisian model, Rue 89.

Even though the directors of Libération had no specific model when they launched LibéToulouse as an experiment, Libévilles blog network became an integral part of the newspaper's web strategy. At the end of 2009, Libération began to charge subscription fees for accessing its online edition. Such a decision consequently impoverished Libération.fr's content as it was subsequently exclusively provided by the web news team, press agencies and the journalists' blogs. Thus the creation of LibéToulouse resulted in the newspaper's decision to launch a platform of blogs run by some of its journalists.

After half a day's training on website management at the Paris office, Gilbert Laval was placed in charge of LibéToulouse. He was assigned the mission of carrying on the same job he had already been doing for the print edition, and augmenting the number of articles. Just like the other two Libération local correspondents, his objective was to find local Toulouse news likely to interest the newspaper's readers. When we met the journalist, he admitted that he was not only writing for Toulouse readers, but for readers all over France. Effectively, the production of daily news articles and the desire to encourage debate with readers in-the-know about the city's issues necessitated a focus on very local activities, whose analysis and reporting were nevertheless consistent with the editorial framework of the national edition. At Carré d'info, although the editorial framework was in line with the national ones, it did not result from any 
external influence. It resulted from the journalists' representations and coverage of inner city news in a regional metropolitan area. The journalists kept themselves informed of their counterparts' activities in other cities (Rue 89 Lyon, Strasbourg, Dailynord, Dijonscope were mentioned several times during the interviews). In return, they were willing to provide their colleagues with newsworthy items about their own regions. All of them were members of the Syndicat de la Presse Indépendante d'Information en Ligne Spiiß5 (an independent pure players union) and shared a vision of journalism similar to their national counterparts (LE BOHEC, 2000). They sought unconventional news that would be of particular interest to a cultivated audience concerned with social issues. For example, topics on racism, sexual minorities, or the environment were frequently addressed from a local perspective. The criteria used to evaluate the interest in a topic came mainly from the journalists' personal position and education. Even though national pure players were sometimes criticized for being over-cautious or for favouring communication investigation, Carré d'Info modelled itself after them, working to a news model relating to national public space, reaffirming one of the basic principles of French local journalism (DE LA HAYE, 1985).

\section{ABSENCE OF VIABLE BUSINESS MODELS}

Another characteristic these websites share is that they both disappeared after failing to develop stable business models. LibéToulouse's disappearance is the result of several factors relating to Libération's inability to break even financially. Libération's local editions did not generate any significant advertising revenue. For that reason, all LibéVilles sites run by contracted stringers disappeared in 2011 (LibéBordeaux shut down in 2010 after a stringer left and was not replaced), even despite strong reader reactions, such as in Orléans where 1200 people signed a petition in hopes of keeping the site active. As mentioned before, only the three sites that had contracted journalists remained active. Working for the LibéVilles sites was time-consuming, and the journalists either did a rush job for the print edition or abandoned it. The financial decline of the newspaper and the development of its online strategy forced the directors to reconsider their position on the three surviving Libévilles sites. It was an untenable position: they generated no revenue, were too expensive in terms of labour costs, and did not fit into the newspaper's overall online strategy. Today, the newspaper's strategy remains uncertain. After experimenting with free 
unlimited access, full paywall and a freemium model (free online access and charging for printed content), Libération now stands mid-way: the print edition is reserved for subscribers on the day it is published, but available to everyone the following day. The local news sector, in which Libération expressed more interest than any other national newspaper (RAMPON, 1999), is no longer a priority in today's age of economic uncertainty.

Carré d'info had a profit of 12,000 euros in its last financial year (2013), with $60 \%$ of the revenue coming from advertising and $40 \%$ from training programmes run by its staff. The website's journalists did not receive salaries. To avoid legal constraints, they were paid as stringers and given token sums. Therefore, to ensure their daily needs during the two-year adventure, they depended on other sources of income (such as social and unemployment benefits, family support). Moreover, two of the journalists taught at journalism school and university, their fees being invoiced under the company's name. Seeing training as a growing market, Carré d'info requested to be officially recognized as a training organization, but was turned down ${ }^{6}$. The business plan set up by the founders of Carré d'info did not work out as planned. The website achieved a respectable audience level, but the advertising revenue did not come through due to the poor local advertising market, but mainly due to a lack of business skills. After the adventure was over, the journalists came to the bitter conclusion that local journalism as they practiced it was not profitable per se. In order to operate competitively, additional activities would have been necessary to ensure profitability (such as public relation and institutional communication services, etc.), but they could not or did not want to develop them.

\section{CONCLUSION}

When attempting to summarize the situation of local news in France, one has to admit that few changes have occurred in the organization of the local political spaces. In terms of audience rating, the traditional actors in the regional press dominate both online and in print, with a higher number of readers than that of newcomers. Moreover, online competition tends to be more and more lurid and sensationalist, in contrast with national media. Newcomers struggle to achieve sustainable business models, which are even more precarious than the national pure players' ones. It seems that neither the subscription model nor the advertising model generates enough 
revenue to sustain an online local news site, and that the activity is economically viable only if additional activities supplement it (website building, public relations, training, charging for services...). We can see proof of this in the bankruptcies of Carré d'info and Dijonscope in 2013 and in the financial problems met by pure players in many cities (Amiens, Lyon, Strasbourg, etc.), threatening their future existence. Finally, despite the diversity in technical capability and committed actors, the end of Libévilles system is further proof of the difficulties encountered upon creating economically viable journalistic spaces for discussion and debate on local and regional politics.

Nevertheless, our field survey of the Toulouse area has revealed some new tendencies and practices towards a positive change in the concept of local news. The two actors we observed practiced independent journalism even though it put them in direct critical opposition to local institutions. Although precarious and short-lived, their existence became an encouraging indication of a specific desire to animate the local public space. Moreover, LibéToulouse and Carré d'info's editorial lines seemed to differ from the official agenda and (in Carré d'info's case) did not follow the obligation shared by all the regional actors to reserve a large space to sports and sensationalist news. This characteristic, already being demonstrated by national pure players, is also exemplified at a local level.

Furthermore, our two case studies demonstrate that contrary to the cliché of online media defined as "desk journalism", online journalism can be classed as "outdoor journalism" when practiced locally. It is even truer considering that recognition from local actors of social and political life (vital to the everyday practice of local journalism) requires regular contact and presence on the field.

There remains the economic question. Among the new local media, only those providing leisure activities information (outside editorial content) have achieved a stable business model, such as Toulouseweb or Toulouseblog 7 . Today, local pure players with renewed editorial approaches have not yet obtained economic stability and cannot expect to survive in the current economic market.

This situation, which might seem sad from a democratic point of view, was the same at Libération, in 1944, when the French provisional government regarded information essential to the proper functioning of democracy and aspired to remove it from the market economy.

In order to facilitate the adaptation of local news to the transformation of territorial democracy, there appears to 
be an urgent need to find financial solutions in order to prevent the disappearance of the new online actors, and in doing so, to completely overhaul the press aid system ${ }^{8}$.

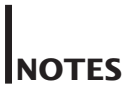

1 The interviewees are Gilbert Laval (LibéToulouse, April 2013), Bertrand Enjalbal, Xavier Lalu, Pauline Croquet and Xavier Druot (Carré d'info, February 2013).

2 Gilbert Laval started out as a stringer for Libération when the newspaper was founded. Then he worked for La Dépêche du Midi in the Tarn region before being hired to develop the LibéToulouse project. Since the failure of the project, he has worked as a political journalist for Libération in Toulouse.

3 Contextualization was often provided by users, as we will see further.

4 Aqui.fr is a regional pure player covering the entire Aquitaine region. It was founded in 2007 by former Sud-Ouest editor Joël Aubert.

5 On its website, Spiil defines its mission as: "to study, represent and defend the professional, economic, deontological, material and moral interests of independent online press publishers, both general and specialized".

6 Pure player Aqui.fr was recognized as a training organization for elected officials, which brings in some useful revenue.

7 Leisure activities directories with no editorial content, serving as ad grabbers and as a self-promoting tool for companies which produce them.

8 According to the National Audit Office's report published in 2013, state aid to the press amounted to $€ 5$ billion for the period 20092011 , most of which went to publications that were not generalinterest newspapers.

\section{BIBLIOGRAPHY}

BOUSQUET, F.; MARTY, E.; SMYRNAIOS, N. Les nouveaux acteurs en ligne de l'information locale: vers une relation aux publics renouvelée? Colloque Le journalisme en ligne et ses publics. Bruxelas: Université Libre de Bruxelles, 4-6 dezembro, 2013. 
BOUSQUET, F.; SMYRNAIOS, N. L'information en ligne et son territoire: positionnement comparé entre un pure player départemental et un quotidien régional. In : NOYER, J.; RAOUL, B.; PAILLIART, I. (orgs.). Médias et territoires: permanences et mutations. Lille: Presses universitaires du Septentrion, 2013.

BOUSQUET, F.; SMYRNAIOS, N. Les nouveaux modèles économiques et éditoriaux en Région Midi-Pyrénées. Rapport de recherche auprès de la Région Midi-Pyrénées, 2010.

CARDY, H. Construire l'identité régionale: la communication en question. Paris: L'Harmattan, 1997.

DE LA HAYE, Y. Dissonances: critique de la communication. Grenoble: La Pensée Sauvage, 1984.

DE LA HAYE, Y. Journalisme, mode d'emploi: Des manières d'écrire l'actualité. Paris: L'Harmattan, 1985.

ESTIENNE, Y. Le journalisme après Internet. Paris: L'Harmattan, 2007.

FEYEL, G. La presse en France des origines à 1944: histoire politique et matérielle. Paris: Ellipses, 1999.

FRISQUE, S. Une reconfiguration des espaces médiatiques et politiques locaux? Revue française de science politique, v. 60, n. 5, p. 951-973, 2010.

GIMBERT, C. Le correspondant, un amateur de local engagé par son territoire. Sciences de la société, n. 84-85, p. 51-65, 2012.

GUISNEL, J. Libération, la biographie. Paris : La découverte, 2003.

LE BOHEC, J. Les Mythes professionnels des journalistes. État des lieux en France. Paris: L'Harmattan, 2000.

LE FLOCH, P. Économie de la presse quotidienne régionale. Paris: L'Harmattan, 1997.

MARTIN, M. La presse régionale: des affiches aux grands quotidiens. Paris: Fayard, 2002.

MARTY, E. et al. Diversité et concentration de l'information sur le web. Une analyse à grande échelle des sites d'actualité français. Réseaux, $n$. 176, p. 27-72, 2012.

PAILLART, I. Les territoires de la communication. Grenoble: Presses universitaires de Grenoble, 1993. 
RAMPON, J.-M. Mesures du discours éditorial de Lyon-Libération (1986-1992): dire l'urbain au quotidien. 273 f. Tese de doutorado. Lyon: Université Lumière Lyon 2, 1999.

RINGOOT, R.; ROCHARD, Y. Proximité éditoriale: normes et usages des genres journalistiques. Mots, n. 77, p. 73-90, 2005.

SMYRNAIOS, N. Les pure players entre diversité journalistique et contrainte économique: les cas d'Owni, Rue89 et Arrêt sur images. Recherches en communication, n. 39 (no prelo), 2014.

Franck Bousquet is an associate professor of Information and Communication Studies at LERASS, at the University of Toulouse III. His research interests lie in local journalism and its ongoing transformation, using a communicational approach towards integrating its economy and history.

Nikos Smyrnaios is an associate professor of Information and Communication Studies at LERASS, at the University of Toulouse III. His research focuses on Socio-economics and the Internet, and online journalism. E-mail: nicolaos. smyrnaios@iut-tlse3.fr

Dominique Bertelli is an associate professor of Information and Communication Studies at LERASS, at the University of Toulouse III. He has published several articles on literary reception by the press. $\mathrm{He}$ is also a specialist on the works of French writer Georges Pérec. E-mail: dominique.bertelli@iut-tlse3.fr 